\section{Elendig inneklima i sykehusene}

Sykepleiere og andre ansatte i norske sykehus har dårligst inneklima i landet. Dårlig fysisk arbeidsmiljø. som ventilasjon og temperaturforhold, er noe av det som stjeler mest energi på jobben.

- Jeg mener de norske helseforetakene misligholder offentlig eiendom. I 2011 refset Riksrevisjonen drift og vedlikehold av norske sykehusbygg, som hadde sopp, vannskader, dårlige tak og fuktighet. Men forfallet fortsetter. Det merkelige er at ingen gjør noe med det, sier overlege i Arbeidstilsynet, Jan Vilhelm Bakke til Tidsskriftet.

\section{Verst i sykehusene}

Tall fra Statistisk sentralbyrå viser at sykepleiere har dårligst inneklima av alle yrkesgrupper (1). I tillegg er det mye unødvendig eksponering for desinfeksjons- og rengjøringsmidler. Kjemikalier i sprayform er ifølge Bakke verst.

I en undersøkelse TNS Gallup har gjort for Enova, har yrkesaktive kontorarbeidere svart på hvilke faktorer som gjør at de eventuelt føler seg uopplagt på jobb. $58 \%$ svarte at forhold knyttet til ventilasjon hadde stor betydning. Også temperatur var svært viktige faktorer for over halvparten av de spurte.

- Dårlig luftkvalitet kan føre til tretthet, hodepine, irriterte luftveier og hudproblemer. Mange astmatikere blir verre på jobben. Det er også påvist at for høy og for lav temperatur reduserer konsentrasjon og produktivitet, sier Bakke.

\section{Erfarte helseplager}

Kari Tveito har jobbet som overlege ved CFS/ME-senteret i høyblokka på Aker sykehus og kan bekrefte at dårlig inneklima kan føre til helseplager.

- Ved en uformell spørreundersøkelse blant de ansatte på senteret i 2013, kom det frem at nesten alle de spurte hadde opplevd helseplager som de knyttet til det dårlige inneklimaet. Flere valgte å kle ekstra godt på seg for å kunne ha vinduet oppe om vinteren. De vanligste plagene var hodepine, nedsatt konsentrasjonsevne og redusert arbeidskapasitet. Det var så ille at jeg i en periode lånte kontor $\mathrm{i}$ andre deler av sykehuset, sier Tveito.

\section{Tas på alvor}

Avdelingsleder Nina Skylv ved Arbeidsmiljøavdelingen ved Oslo universitetssykehus sier de tar de ansattes arbeidsmiljø på alvor.

- Inneklima kommer på tredjeplass over arbeidsmiljøutfordringer ved Oslo universitetssykehus. Vi har bygningsmasse av nyere dato som har tilfredsstillende inneklima, men vi har også gammel og nedslitt bygningsmasse som trenger oppgradering, for eksempel på Radiumhospitalet og på Ullevål. Det er utarbeidet en prioritert tiltaksplan for perioden 2014-2025 som skal ivareta dette, sier hun.

\section{Eline Feiring \\ Tidsskriftet}

\section{Litteratur}

1. Statistisk sentralbyrå. Levekårsundersøkelsen 2009. http://ssb.no/arbmiljo/ (18.3. 2014).

\section{Ridder av 1. klasse}

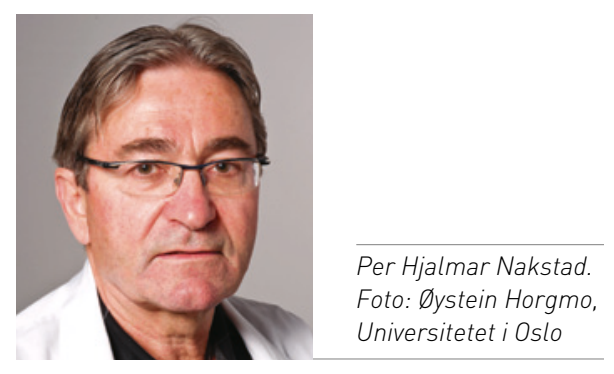

Per Hjalmar Nakstad (f. 1946) er utnevnt til ridder

1. klasse av St. Olavs Orden for sin innsats innen nevroradiologi.

Nakstad tok medisinsk embetseksamen i Freiburg, Tyskland i 1971, ble godkjent spesialist i radiologi i 1979 og tok doktorgraden i 1985.

Han har vært ansatt $\mathrm{i}$ to perioder både ved Rikshospitalet og ved Ullevål, blant annet som seksjonssjef og avdelingsoverlege.

Fra 1992 og frem til i dag har han vært professor ved Universitetet i Oslo. I tillegg har han fra 2009 og frem til i dag vært forskningsleder for Avdeling for radiologi og nukleærmedisin ved Oslo universitetssykehus, og har også innehatt en rekke andre verv.

\section{Ridder av 1. klasse}

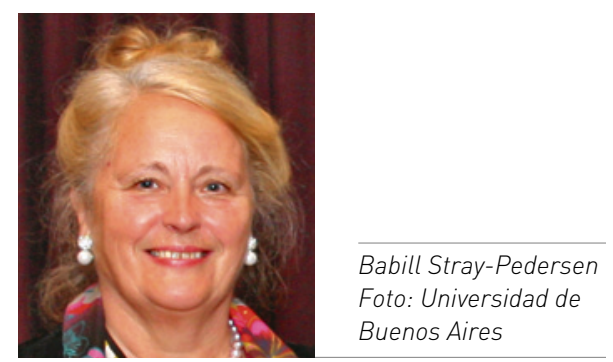

\section{Babill Stray-Pedersen (f. 1943) er utnevnt til ridder 1. klasse av St. Olavs Orden for sin innsats for fødende kvinner og nyfødte barn.}

Hun tok medisinsk embetseksamen i Oslo i 1969, doktorgrad i 1979 og ble godkjent spesialist i fødselshjelp og kvinnesykdommer i 1985 .

Helt siden begynnelsen av 1970-årene har hun arbeidet med kvinnehelse. Som kliniker gikk hun gradene fra assistentlegevikar til seksjonsoverlege for fødeavdelingen ved Aker sykehus, for senere å bli professor ved Universitetet i Oslo.

Stray-Pedersen er også kjent som landets første «ukebladlege», noe som ga henne et unikt innblikk i kvinners helseplager. 